\title{
Ігор ТКАЧЕНКО
}

кандидат історичних наук, провідний науковий співробітник, сектор суспільних наук, науково-організаційний відділ Президії НАН України

(Київ, Україна), tkachenko@nas.gov.ua

ORCID: https://orcid.org/oooo-0oo2-8276-3778

\section{Видавнича діяльність М.Грушевського в Києві 1907-1914 рр. як складова грушевськознавства: епістолярно-публіцистичний аспект}

DOI: https://doi.org/10.15407/uhj202I.05.023

УДК: 930.I(477)《1907/1914»:929Грушевський]:655.4I

\begin{abstract}
Анотація. Мета статті полягає в розгляді видавничої діяльності в період до Першої світової війни як одного з ключових напрямів громадсько-політичної активності й одного з аспектів грушевськознавства, роль та значення котрого потребують більшої уваги дослідників життя і суспільної праці М.Грушевського. Методологія основана на комплексному аналізі джерел, які репрезентують видавничу діяльність М.Грушевського, його роль як видавця й одноосібного керманича «ЛНВ», «Села», «Засіву». Використання проблемно-пошукового методу в поєднанні з критичним аналізом студій, присвячених М.Грушевському, дає можливість розглянути основні аспекти та особливості погляду дослідників на його видавничу діяльність в контексті загальної суспільно-політичної і громадської праці. Наукова новизна. Розкриваються місце і значення видавничої діяльності як важливої складової грушевськознавства. Аналіз публікацій, котрі стосуються життя й діяльності М.Грушевського до початку Першої світової війни, дозволяє стверджувати, що саме видавнича активність, дієвий і постійний контроль над «ЛНВ», «Селом» і «Засівом» вможливили посилення позицій М.Грушевського як лідера українського національного руху. Висновки. Видавнича справа була одним із ключових напрямів діяльності М.Грушевського. Показано, що переведення «ЛНВ» до Києва в 1907 р. сприяло не лише єднанню обох частин України, розділених кордонами, але й зростанню його одноосібного впливу на журнал, за допомогою чого він утвердився як головна постать національного руху. Видавнича діяльність М.Грушевського слугувала не лише формуванню та поширенню українських ідей, але й зростанню його особистого впливу та значення у суспільстві.
\end{abstract}

Ключові слова: Грушевський, видавнича діяльність, грушевськознавство, український національний рух.

Дослідження історичних процесів, які відбувалися на українських землях на початку XX ст., і наслідком котрих стала революція 1917-1921 pp., нині надзвичайно актуальне. Започатковане в еміграції під егідою журналу «Український історик» і професора Л.Винара студіювання наукової, політичної, публіцистичної спадщини М.Грушевського спричинилося до заснування грушевськознавства як спеціальної галузі історичної науки, що займається міждисциплінарним дослідженням різноманітних аспектів життя і творчості знаного історика, політика, державного та громадського діяча, роль якого в національному житті - «конструктор модерної української нації» - визначив провідний вітчизняний грушевськознавець І.Гирич.

\footnotetext{
1 Гирич I. Михайло Грушевський: конструктор модерної української нації. - К., 2016. - 840 с.
} 
Роль Л.Винара як популяризатора студій із життя і творчої спадщини М.Грушевського розглянуто у праці М.Ковальського та А.Атаманенко 2 Справді, внесок Л.Винара у становлення грушевськознавства очевидний. Він - автор численних публікацій, які заклали основи цієї дисципліни. Не маючи доступу до корпусу матеріалів про М.Грушевського в архівах і бібліотеках Києва та Львова, Л.Винар користувався лише доступними закордонними матеріалами й опублікованими джерелами. Відповідно, далеко не все, що стосується змістовного наповнення грушевськознавства, було предметом тодішніх студій. Нові можливості в повній мірі репрезентувати творчу спадщину М.Грушевського, утвердити його роль і значення у формуванні сучасної державності з'явилися з проголошенням незалежності України в І99і р. Відкинувши застарілі ідеологічні конструкції та шаблони радянської доби, грушевськознавство отримало потужний творчий імпульс.

У статті «Вступ до грушевськознавства: Думки з приводу п’ятдесятих роковин смерті Михайла Грушевського» Л.Винар указував, що «кожна академічна дисципліна має свою структуру і свою специфічну побудову. В цьому відношенні грушевськознавство не $є$ винятком. Ця нова ділянка наукового дослідження охоплює три основні частини: І) джерела і бібліографічні дослідження, 2) досліди життя і діяльності М.Грушевського і 3) дослідження його творчості (наукові, публіцистичні і белетристичні праці)». Він також визначив три напрями загальної діяльності М.Грушевського, а саме наукову, суспільно-політичну та культурно-освітню, віднісши до останньої заснування видавництв, часописів, їх редагування³.

Серед досліджень останніх років слід виокремити монографії І.Гирича ${ }^{4}$, Р.Пирога й В.Тельвака', в яких усебічно представлено постать М.Грушевського, у тому числі його участь у створенні та реалізації видавничих проектів у Києві після революції 1905 р. Також у контексті публіцистично-видавничої роботи слід згадати дисертацію С.Панькової, в якій розкривається роль М.Грушевського як видавця й редактора, чию увагу було зосереджено на формуванні концепції, редакційного портфеля «Літературно-наукового вістника» та «Села», на перманентній боротьбі з опонентами, цензурою ${ }^{6}$.

Підтримуючи думку Л.Винара й Р.Пирога, що кожен напрям творчої, суспільної, політичної роботи М.Грушевського має бути висвітлений у рамках грушевськознавства, чому повинні слугувати тематичні дослідження відповідних сюжетів у рамках видання повного รо-томного зібрання праць та його епістолярію у серії «Епістолярні джерела грушевськознавства», слід звернути увагу не лише на М.Грушевського як історика, державного діяча, але й видавця, власника газет і журналів․ Кожна ділянка творчості вченого та громадсько-політичного діяча вимагає грунтовного джерельного аналізу, виготовлення відповідної моделі, в якій було б подано ії структуру, методологію, джерельно-бібліографічну основу ${ }^{8}$

Утім дослідники постаті М.Грушевського активно вивчають далеко не всі можливі аспекти його суспільної праці. Так, він практично відсутній у розвідках істориків

\footnotetext{
2 Ковальський М., Атаманенко А. Теоретичне обгрунтування грушевськознавства (до 70-ліття Любомира Винара) // Проблеми історії України: Факти, судження, пошуки. - Вип.10. - К., 2004. - С.30-41.

3 Винар Л. Михайло Грушевський: історик та будівничий нації: Статті та матеріали. - К., 1995. - С.155-156.

4 Див. прим.1.

5 Пиріг P., Тельвак В. Михайло Грушевський: біографічний нарис. - К., 2017. - 576 с.

6 Панькова С. Публіцистика Михайла Грушевського як джерело дослідження суспільно-політичної думки в Україні кінця XIX - початку XX ст.: Дис. ... канд. іст. наук. - К., 2018. - 305 с.

7 Пиріг Р. Грушевськознавство: стан та перспективи розвитку // Український історичний журнал. - 1996. - №5. C.71-82.

8 Винар Л. Вступ до науки грушевськознавства // Український історик. - 1996. - №4. - С.39.
} 
як одноосібний видавець, редактор і фактичний власник «ЛНВ», «Села», «Засіву», інших газет, журналів, наукових збірників, ініціатором та засновником котрих став як у Львові, так і в Києві після 1907 р.

Прагнучи історичної достовірності й об'єктивності оцінки тих чи інших фактів історії, видатних постатей минулого, слід звертати увагу в тому числі на те, що писав із того чи іншого приводу сам досліджуваний діяч. Автори біографічного нарису, присвяченого І5о-річчю від дня народження М.Грушевського, указують на те, що «з батьківських захоплень на все життя успадкував Михайло інтерес до книгарської та видавничої справи», підкріплюючи цю тезу його власними словами («але найбільше все-таки зацікавлення з батьківської діяльності в мені будила книгарська і видавнича сфера, звідки веде свій початок моє замилування до сього діла, яке зісталось, може, найбільшою і найтривкішою пасією всього мого життя»)9.

Підтвердження того, що видавнича справа була одним із пріоритетів М.Грушевського, знаходимо у величезній кількості джерел, зокрема епістолярній спадщині, наукових працях представників діаспори та сучасних дослідників. Ні для кого з істориків не секрет, що М.Грушевський був ініціатором створення «ЛНВ» у І898 р., що видавничій справі в період до 1914 р. присвячено потужний епістолярний масив, і що саме вона, видання «ЛНВ», «Села», «Засіву» як основний сюжет займає цілі томи (наприклад, 6-й) «Епістолярних джерел грушевськознавства». І.Гирич стверджує як факт, що М.Грушевський не лише був засновником нового типу журналу він був визначним знавцем сучасної йому європейської художньої літератури й навіть визначав літературні смаки «українського громадянства» ${ }^{10}$.

В який спосіб М.Грушевський настільки потужно впливав на українську громадськість? Безперечно, науковими працями. Але водночас - і своєю діяльністю як видавець, редактор, фактичний та одноосібний власник газет, журналів, ідеолог і публіцист. Підтвердження цьому ми знайдемо в його листуванні з Є.Чикаленком, В.Винниченком, О.Олесем, І.Джиджорою, Ю.Сірим (Тищенком), І.Лизанівським, М.Гехтером, М.Шаповалом, М.Коцюбинським та ін., у публіцистиці М.Грушевського на шпальтах «ЛНВ», «Села», «Засіву», «Ради», «Діла», у полемічних, конфліктного й ідеологічного характеру статтях про його діяльність у «Ділі» 1908 та І9Іі рр., «Раді» І9п р., статтях та оглядах С.Петлюри у «Слові», М.Шаповала в «Українській хаті», М.Гехтера у «ЛНВ», в архівних фондах органів влади, у мемуарній літературі. Це все складає джерельну основу вивчення видавничої діяльності М.Грушевського.

Дослідники в галузі грушевськознавства ще в 1990-х рр. заклали теоретичний фундамент дисципліни, визначивши основні напрями студій, які є частиною загального вивчення подій української історії XX ст., доби національного відродження й боротьби на незалежність. М.Грушевському відводиться ключова роль у процесі державотворення, адже він був не лише істориком, публіцистом чи політиком - він став апологетом українства як такого, його ідеологом. Контроль над єдиним усеукраїнським часописом, яким був «ЛНВ», посилив його позиції як чільного діяча. Визначаючи одноосібно напрям і наповнення видання, що стало особливо помітно після перенесення журналу до Києва в 1907 р., М.Грушевський немов локомотив розганяв український рух, надаючи йому загальнонаціонального характеру.

Засновані й редаговані М.Грушевським «Літературно-науковий вістник», інші видання мали великий вплив на формування національного світогляду, розбудову культури, розвиток політичного життя в Наддніпрянській і Наддністрянській

\footnotetext{
9 Пиріг P., Тельвак В. Михайло Грушевський: біографічний нарис. - С.20.

${ }^{10}$ Гирич I. Михайло Грушевський: конструктор модерної української нації. - С.60-61.
} 
Україні. Він був одним із найвидатніших українських публіцистів ХХ ст., тож без систематичного вивчення його спадщини неможливе об'єктивне висвітлення й аналіз життя, діяльності, творчості ${ }^{\text {II }}$.

Водночас слід поставити питання про належне висвітлення видавничого аспекту як самостійного явища. Здобутки грушевськознавства за період незалежності України узагальнено в доповіді І.Гирича, виголошеній на засіданні Президії НАН України 28 вересня 2016 р., у переддень І5о-річного ювілею М.Грушевського ${ }^{12}$. Однак авторитетний грушевськознавець жодним чином не виокремлює постать М.Грушевського як видавця. Хоча свідчити на користь цієї його іпостасі мала хоча б згадана ним серія «Епістолярні джерела грушевськознавства». Так, виданий 2012 р. 6-й том цілком і повністю присвячений М.Грушевському як видавцеві й редакторові «ЛНВ», «Села», «Засіву», його участі в інших видавничих проектах у період після перенесення «ЛНВ» до Києва ${ }^{13}$. Видавничі сюжети яскраво простежуються й в інших опублікованих томах листування М.Грушевського: зі І.Джиджорою ${ }^{14}$, Є.Чикаленком ${ }^{15}$, С.Єфремовим, О.Олесем ${ }^{16}$. Ще більше листів М.Грушевського й до нього очікують на публікацію. Адже, за свідченням І.Гирича, у фонді родини Грушевських у Центральному державному історичному архіві України в Києві зберігається близько I5 тис. листів до нього від понад г тис. адресатів, його ж власних листів налічується до г тис. ${ }^{17}$ Зростання кількості публікацій епістолярних джерел грушевськознавства свідчить про те, якої великої ваги надають йому дослідники життя й діяльності М.Грушевського.

Поряд із публіцистикою М.Грушевського та матеріалами преси листування виступає тим джерелом, яке найглибше репрезентує його як видавця, редактора, ідеолога української преси. Далеко не з усіма своїми адресатами він спілкувався на суто видавничі теми, але можна впевнено стверджувати, що цим сюжетам присвячено значну частину кореспонденції. Видавничі сюжети зустрічаються в листуванні М.Грушевського зі співробітниками київської редакції «ЛНВ». Так, у 1907 р. всю технічну роботу тут виконували Л.Лукич (його ж листи - загалом г87 - знаходимо під псевдонімом М.Котика та Л.Будая) ${ }^{18}$ та І.Джиджора (I48 листів), а з осені цього ж року - Л.Лукич і Ю.Сірий (Тищенко) (347 листів). Листування з ними становить важливу частину джерел з історії видавничої діяльності М.Грушевського в Києві.

Серед кореспонденціі у фонді Грушевських - листи від В.Винниченка, М.Вороного, М.Гехтера, Л.Жебуньова, Н.Кибальчич, Ю.Кміта, Ф.Матушевського, С.Русової, П.Стебницького, Л.Старицької-Черняхівської, М.Шаповала та ін. У більшості з них ідеться про справи, пов’язані з виданням «ЛНВ», «Села», «Засіву», до яких вони були залучені. У листуванні з публіцистами М.Гехтером, М.Вороним, М.Шаповалом обговорюються справи участі у виданнях М.Грушевського, друку

\footnotetext{
${ }^{11}$ Винар Л. Вступ до науки грушевськознавства. - С.45.

12 Гирич I. Досягнення і перспективи розвитку сучасного грушевськознавства (до 150-річчя від дня народження М.С.Грушевського) // Вісник НАН України. - Вип.11. - К., 2016. - С.33.

13 Листування Михайла Грушевського: Листування Михайла Грушевського та Юрія Тищенка / Упор. О.Мельник. - К., 2012. - 640 с. (серія «Епістолярні джерела грушевськознавства», т.6).

${ }_{14}$ Листування Михайла Грушевського: Листування Михайла Грушевського та Івана Джиджори / Упор. С.Панькова, В.Пришляк. - К.; Нью-Йорк; Париж; Л.; Торонто, 2008. - 552 с. (серія «Епістолярні джерела грушевськознавства», т.4). 15 Листування Михайла Грушевського: Листування Михайла Грушевського та Євгена Чикаленка / Упор. І.Старовойтенко, О.Тодійчук. - К.; Нью-Йорк; Париж; Л.; Торонто, 2010. - 296 с. (серія «Епістолярні джерела грушевськознавства», т.5).

${ }_{16}$ Листування Михайла Грушевського / Упор. Г.Бурлака. - К., 1997. - 399 с.

${ }^{17}$ Гирич I. Архів М.С.Грушевського як джерело для вивчення діяльності визначних постатей українського руху: Автореф. дис. ... канд. іст. наук. - К., 1996. - С.2.

${ }^{18}$ Центральний державний історичний архів України, м. Київ (далі - ЦДІАК України). - Ф1235. - Оп.1. - Спр.561. - 189 арк.
} 
статей, інші аспекти редакційної роботи. У кореспонденції з поетами та письменниками частіше за все обговорювалася публікація їхніх творів у редагованих М.Грушевським часописах.

Видання журналу було справою життя М.Грушевського. «ЛНВ», який від початку існування виступав як усеукраїнський, із 1907 р. опинився під його повним контролем, він провадив більшу частину редакційної роботи - займався підбором матеріалів, перечитував рукописи поданих творів і статей ${ }^{19}$. «ЛНВ» об’єднував навколо себе кращі публіцистичні та літературні сили обох частин України. Практично всю роботу з дописувачами, співробітниками київської й львівської редакцій журналу також проводив М.Грушевський. Яскраве свідчення цього - його листи та листи до нього. Слід відзначити, що в листуванні ми можемо простежити не лише шляхи, якими вів «ЛНВ» його фактичний власник, але й аспекти взаємодії чи не всіх причетних до часопису людей. Добір кадрів, проваджена в «ЛНВ», «Селі», «Засіві» редакційна політика, конфлікти, причиною яких був М.Грушевський і в яких яскраво проявлялися аж ніяк не «пряничні» риси його характеру - усе це свідчення того, що він безумовно розумів, як контроль над друкованими органами значно посилює статус громадського діяча, є зручною трибуною для просування власних поглядів та ідей. Переведенням «ЛНВ» до Києва вдалося не лише підвищити статус журналу як усеукраїнського, але й збільшити особистий вплив на національне життя.

Отже переїзд у Київ не лише закріпив роль М.Грушевського як єдиного (а не у складі тріумвірату зі І.Франком і В.Гнатюком) редактора журналу, але й став серйозним підгрунтям для виступів від імені обох частин України. У листуванні та публіцистиці М.Грушевського домінувала думка, що видання мало стати об'єднуючим фактором для галичан і наддніпрянців, а сам він виступав не як галичанин, а як українець у широкому сенсі слова. Звичайно, далеко не всі національно орієнтовані кияни були раді такому серйозному конкуренту. Журнал «Україна» не витримав конкуренції з «ЛНВ», а його видавці відійшли на другі ролі в національному житті та вважали професора головним джерелом своїх «бід».

М.Грушевський був особливо активним в управлінні видавничим процесом, постійно перебуваючи в пошуку нових літературних сил. Саме його стараннями до участі у «ЛНВ» долучилися О.Олесь, В.Винниченко, Леся Українка, М.Коцюбинський та ін. У листах до найближчих співробітників журналу М.Грушевський повідомляв про плани перенесення видання до Києва, цікавився, як позначиться факт переїзду на їх співпраці з журналом. У грудні 1906 р. він писав П.Стебницькому, постійному оглядачеві «ЛНВ», що виїхав у Київ у справі реорганізації «Ради» та облаштування справ часопису. Повідомляючи про подання на дозвіл видавати «ЛНВ» він запрошував адресата до участі у журналі ${ }^{2}$. П.Стебницький погодився й долучився до всіх київських проектів М.Грушевського. Так само М.Грушевський запрошував до «ЛНВ» і М.Коцюбинського. У своєму листі від 19 грудня 1906 р. він писав: «За по днів вибираюсь до Києва налагоджувати I книжку. На що я міг би надіятися від Вас? Чи маєте що з белетристики, чи може яку статтю на біжучі теми?» ${ }^{21}$. Звертався й до інших письменників і публіцистів, котрі збагатили «ЛНВ» своїми творами в 1907-І914 рр. Щоправда, не всі давали М.Грушевському позитивну відповідь. Так, Ф.Матушевський на пропозицію «ближчої участі» у виданні повідомив: «[...] не знаю, що Вам і сказать, не через те, що я вагаюся, і рахуюся більше з інших, незалежних від мене причин»²2.

\footnotetext{
${ }^{19}$ Винар Л. Михайло Грушевський: історик та будівничий нації. - С.84.

${ }^{20}$ Інститут рукопису Національної бібліотеки України ім. В.І.Вернадського. - Ф.ІІІ. - Од.зб.52082. - Арк.2.

${ }^{21}$ Горинь В. Листи М.Грушевського до М.Коцюбинського // Український історик. - 2002. - №1/4 (152/155). - С.441.

${ }^{22}$ ЦДІАК України. - Ф.1235. - Оп.1. - Спр.634. - Арк.46.
} 
Постійно перебуваючи в роз`іздах, М.Грушевський змушений був контролювати роботу «ЛНВ» упродовж першого київського року шляхом листування із співробітниками редакції, які були прислані зі Львова для ведення журналу, адже розраховувати на участь киян не доводилося. Ідеться про І.Джиджору, І.Кревецького, Л.Лукича. Згодом до них приєднався Е.Квасницький-Трейман, який відповідав за експедицію видання по Україні. Листування М.Грушевського з ними є одним із джерел вивчення процесу становлення «ЛНВ» в Києві, та, одночасно, джерелом, що розкриває його роль як редактора, у тому числі й технічного, видавця, ідейного натхненника журналу, кожен аспект роботи котрого перебував під пильним наглядом.

Згадані співробітники мали інформувати М.Грушевського про всі подробиці життя часопису, беручи до уваги, що його київська «прописка» була небажаною не лише для київських опонентів професора, але й для російської влади. Перше, на що слід звернути увагу в листах до М.Грушевського від співробітників його київських видань, це відомості про хід передплати на «ЛНВ». У листі від 20 січня 1907 р. I.Джиджора вказував, що «передплата йде досить добре, на день пересічно 4-5, так що разом буде 350»²3. Ішлося про наддніпрянських передплатників, натомість галицькими опікувався сам М.Грушевський у Львові. І.Джиджора був довіреною особою видавця «ЛНВ» в Києві, повідомляючи про всі прояви місцевого громадського життя. Особливо це стосувалося поточних планів конкурентів у видавничій сфері. Так, в одному з листів він писав, що журнал «Україна» «дотяг» до кількості 400 передплатників i, за словами Д.Дорошенка, його співробітники неабияк заздрили «ЛНВ» ${ }^{24}$, котрий, як повідомляв І.Джиджора, на літо 1907 р. придбали 720 передплатників (це не рахуючи тих, що проживали на Галичині) ${ }^{25}$.

Щодо технічної сторони справи, то нею (до залучення Ю.Сірого) опікувалися Л.Лукич і Е.Квасницький-Трейман. Вони займалися виготовленням та правкою корект, які після цього відправляли на корегування М.Грушевському. І лише після цього аркуші йшли у друк. Відносно експедиції журналу, сам видавець завжди вказував, скільки примірників потрібно надсилати до Львова, а скільки взагалі друкувати. Часто в листах до М.Грушевського технічні працівники запитували його, яким чином формувати структуру у випадку, коли хтось з авторів вчасно не надасть статтю. Так, Е.КвасницькийТрейман у листі від 2 березня 1907 р. повідомляв, що С.Єфремов не прислав свій огляд на 3-й випуск. Зважаючи на це, він зауважував, що «з книжкою ми трохи спізнимося, бо й рукописів до набору зараз нема всіх. До того й корект зі Львова все ще нема» ${ }^{26}$. Затримка виходу нервувала М.Грушевського найбільше, він намагався прищепити працівникам відповідальність за вчасний друк. Часто це залежало лише від спізнення з надсиланням окремих статей. Так, го березня Е.Квасницький-Трейман запитував М.Грушевського, коли до редакції потрапить переклад роману А.Франса «Марі». Він також висловив сподівання, що, можливо, 4-й випуск затримається не так, як це було у випадку з попередніми двома 27. Л.Лукич також повідомляв про обставини, в яких журнал виходив у Києві. За його листами можемо уявити ступінь обурення видавця й редактора журналу недбальством, проявленим співробітниками редакції. Так, в одному з листів Л.Лукич зауважував: «Ви маєте повне право писати так, не тільки як наш хазяїн, але і як чоловік науки, що працює за десяток інших. Але Ви дуже строго дивитесь

\footnotetext{
${ }_{23}$ Там само. - Спр.447. - Арк.18 зв.

${ }^{24}$ Там само. - Арк.41 зв.

${ }_{25}$ Там само. - Арк.60 зв.

${ }^{26}$ Там само. - Спр.522. - Арк.2.

27 Там само. - Арк.4.
} 
на нас» ${ }^{28}$. Виправдовуватися перед М.Грушевським мусив навіть І.Джиджора, який інколи допускав вільне трактування отриманих указівок. Іноді йому доводилося вибачатися, як у випадку з 6-м випуском журналу, коли вчасно не надіслав статті М.Лозинського і вніс зміни до бібліографії ${ }^{29}$. Слід при цьому враховувати неминучість подібних моментів, якщо взяти до уваги, що жодного фахівця з видавничої справи в розпорядженні М.Грушевського не було. Однак часопис під його керівництвом успішно провадив свою діяльність, здобувши за перший київський рік понад 8 оо передплатників.

Відтоді, як до роботи у виданні долучився Ю.Сірий (Тищенко), котрий зумів організувати роботу редакції і книгарні «ЛНВ», проблеми стало вирішувати значно легше. Зустріч зі М.Грушевським у Львові виявилася доленосною для молодого революціонера. Сюжети його життя та листування з істориком детально висвітлені як у його спогадах, так і у студіях, присвячених їхній спільній діяльності на видавничому грунті. 6-й том серії «Епістолярні джерела грушевськознавства» повністю присвячено листовному діалогу Ю.Сірого (Тищенка) зі М.Грушевським. Як справедливо зазначає авторка рецензії на цю публікацію С.Іваницька, найінтенсивнішою кореспонденція між ними була в 1907-1914 pр., а іiі провідною темою стала видавнича діяльність М.Грушевського, передусім питання «ЛНВ» (зокрема формування редакційного портфеля, шрифти, ціни на послуги друкарні, художнє оздоблення того чи іншого числа тощо). Це створювало для впорядників часопису надзвичайно напружений темп роботи ${ }^{30}$.

Ю.Сірий (Тищенко) був не лише креатурою М.Грушевського, але й став у процесі взаємодії з ним безперечним фахівцем у видавничій справі, газетній роботі. Він стояв біля витоків газети «Село», опублікував на іï шпальтах ряд фахових статей, уболівав за роботу редакцій «ЛНВ», «Села», «Засіву». Як писав М.Гехтер,

«під оглядом редакційним праця у “Вістнику” була незвичайно легка й приємна. Статті передавалися Сірому (Ю.Тищенкові), й автор вже більше не мав з ними ніякого клопоту. Грушевський часом писав мені записочки, а то й довші листи, але мова в них була не про написане, а про те, що варто було 6 написати. Ніколи я від нього не чув дрібничкової критики, ніколи він не чіплявся до слів, не впадав у менторський тон, не намагався “впливати”, “вчити”. Він давав мені повну волю й щодо вибору тем і щодо форми, а коли мав яке своє бажання, то висловлював його в делікатній, м'якій, товариській формі. За довгі роки моєї співпраці з ним він ні разу не дав мені відчути різниці в соціальнім положенні, в освіті, у віку, а все поводився зі мною як рівний з рівним» ${ }^{31}$.

М.Грушевський дуже широко бачив видавничу справу. Для нього вона полягала не лише в тому, щоб провадити комерційно успішні проекти (хоч і це важливо), але у залученні до творення української преси тих, хто мав стати його ідейними соратниками, опорою, а не ображеними опонентами.

Як одного з найщиріших прихильників М.Грушевського можна розглядати М.Гехтера. Єврей-вихрест, котрого В.Винниченко з малозрозумілих мотивів зобразив як «жида-кар'єриста» Хаскеля в п'єсі «Співочі товариства», відбувся б як журналіст

\footnotetext{
${ }_{28}$ Там само. - Спр.614. - Арк.30.

${ }^{29}$ Там само. - Спр.447. - Арк.47.

${ }^{30}$ Іваницька С. [рец.]. Листування Михайла Грушевського: Листування Михайла Грушевського та Юрія Тищенка / Упор. О.Мельник; ред. Л.Винар, І.Гирич. - К.; Нью-Йорк; Париж; Л.; Торонто, 2012. - 640 с. (серія «Епістолярні джерела грушевськознавства», т.6) // Український археографічний щорічник: Нова серія. - Вип.18. - К., 2013. - С.753.

${ }^{31}$ Гехтер М. Спогади. Листи до М.Грушевського / Упор., вступ та прим. І.Ткаченка. - К., 2005. - С.23-24.
} 
і без прихильності свого роботодавця у «ЛНВ», «Селі» та «Засіві». Будучи діячем не першого плану, він умів помічати головне - говорячи про події 1907 р. в українському житті, відзначав ключову організаційну роль М.Грушевського у творенні нової українськомовної преси Києва:

«Як Грушевський дав своїх людей до “Ради”, так він взяв людей із “Ради” до свого "Літературно-наукового вістника", до "Записок Наукового товариства ім. Шевченка”, до наприкінці того року заснованих “Студій з поля суспільних наук і статистики”. Він бо розумів справу культурної співпраці й виміни сил між Галичиною та Придніпрянщиною дуже широко. Для нього участь у “Раді” не була якоюсь ізольованою працею, а лише кільцем у ретязі загальної, на всі українські простори й підприемства закроєної культурної акції. Тому він запросив Єфремова писати внутрішні огляди в “ЛНВ”, тому він заохочував мене, Порша, Садовського та ще декого писати рецензії та господарські студії до того ж “ЛНВ”, до “Записок”, “Студій” і т. д. Тому він нарешті подбав про те, щоб “Діло” мало в Києві свого постійного кореспондента, причім вибір редакції, очевидно не без його впливу, впав на мене ${ }^{32}$.

Критикувати ж «ЛНВ» і вміщені на його шпальтах твори для його редактора й видавця було неприйнятним. Жодна стаття не могла бути опублікована без його відома та уважного прочитання. Саме тому розвивався конфлікт з С.Єфремовим. Лист, написаний М.Грушевському 9 липня 1907 р. з приводу огляду для «ЛНВ», свідчить про недопустимість критики на журнал, та ще й на його сторінках. Хоча С.Єфремов і писав, що він
«зовсім не мав на думці писати, як Ви кажете, обжалування проти Вістника і галичан, а просто мені здався цікавим факт з нашого громадянського, - факт, якого не можна не добачати, - i як зумів я, так і занотував його в своїх замітках, щоб звернути між іншим на його увагу в Галичині і тим попередити, може, ще більший розбрат і непорозуміння між галичанами та українцями. Коли ж разом довелося зазначити й деякі хиби Вістника, то тільки для ілюстрації тих відносин, та ще для того, щоб звернути на них увагу й самої редакції» 33 .

Подібні погляди на журнал були неприйнятними для редактора, тож як оглядач «ЛНВ» С.Єфремов перестав його влаштовувати. Наступним став Ф.Матушевський, але й він мав відмінні думки та сміливо їх висловлював. Кореспонденція Ф.Матушевського з М.Грушевським від жовтня 1908 р. розкриває черговий конфлікт, в основі якого були як громадські, так і приватні справи. Лист від 20 жовтня вказує на передумови розбіжностей редактора «ЛНВ» із киянами - він був небажаною персоною в Києві ще до переведення сюди журналу, а Ф.Матушевський називав себе чи не єдиним прихильником такого кроку («3 самого початка, як може пригадуєте собі, коли в августі 1906 року Ви, приїхавши до Києва, повели розмову про перенесення “ЛНВ” до Росії, я здається чи не один тільки й висловився за таке перенесення»). Інформуючи, що «вже прийшов час і мені одстати од Вашого журнала», Ф.Матушевський виступив як від себе, так і від ображеного українського громадянства Києва. Провиною М.Грушевського

\footnotetext{
${ }_{32}$ Там само. - С.19-20.

${ }_{33}$ ЦДІАК України. - Ф.1235. - Оп.1. - Спр.471. - Арк.149.
} 
стали статті в «ЛНВ», спрямовані проти С.Єфремова, а також критична рецензія на «Історію України-Русі» М.Аркаса, науковим редактором якої був В.Доманицький.

«Стаття Ваша в XI кн. за минулий рік мені вельми не сподобалася своїми натяками на людей, яких Ви, не називаючи, правда, на ймення, виставили на людські очі якщо не за ворогів своїх то й не за приятелів. Тим часом сі люди насправді на шкоду журналові, оскільки я знаю, нічого не зробили, окрім того, що не захотіли співробітничати [...] нарешті як особистий друг Василя Миколаєвича, станом здоровля я завжди так турбуюся, я вважаю Вашу пристрастну критику на "Історію" Аркаса занадто жорстоким вчинком над тяжко хворою людиною. Не такий вже він злочинець перед історією рідної країни, щоб можна було його так тяжко карати».

Підсумовуючи, Ф.Матушевський писав, що «великий історик» не зміг утриматися від критики конкурента, адже праця М.Аркаса була більш популярною, а значить комерційно успішнішою за видання самого професора ${ }^{34}$. Слід визнати, що правда у цій історії була не на боці «ЛНВ» і його видавця, хоча рецензія, яка викликала таке обурення, була підписана Ф.Красицьким, а не М.Грушевським.

Вочевидь, не слід зображати М.Грушевського і його діяльність лише в рожевих тонах. Про його складний характер, небажання йти на компроміси, нетерпимість до критики багато згадують дослідники, прихильники, опоненти. Чимало цікавого про стиль управління «ЛНВ» можна дізнатися з брошури г913 р., автор якої зобразив М.Грушевського людиною корисливою, котра здійснює приватну діяльність громадським коштом і не бажає давати звіт у витратах на власні друковані видання, у першу чергу «ЛНВ». Безпринципний ділок (на думку автора), він так вів справу, що «з ініціативи голови товариства і тільки за його вимогою - перенесено до Києва ряд видань (без найменшої об’єктивної причини), а також створено в Російській Україні ряд підприємств сумнівної вартості» ${ }^{35}$.

Більше за все опонентам і критикам М.Грушевського не подобалося, що попри громадську належність (власність «Українсько-руської видавничої спілки») «ЛНВ» фактично був приватним виданням головного редактора. Це викликало численні нарікання в однобокій політиці, зумовленій суто власними інтересами ${ }^{36}$. Також закидали не лише марне витрачання громадських коштів, але й ведення сумнівної підприємницької діяльності. Так, було неможливо встановити належність видань і книготоргівлі в Києві, Катеринодарі, Харкові до об’єктів власності НТШ, нібито М.Грушевський створив перешкоди поверненню вкладених у ці підприємства капіталів ${ }^{37}$. Ще у провину ставилося видання власних «Села», «Засіву» коштом НТШ (оскільки ці часописи були збитковими, М.Грушевський начебто змусив правління товариства покривати дефіцит) ${ }^{38}$.

Слід звернути увагу й на характерну особливість вдачі М.Грушевського - людина заможна, яка отримала солідний спадок від батька, при реалізації власних проектів він віддавав перевагу громадським коштам, а не особистим. Тоді, коли Є.Чикаленко витрачав щороку до 20 тис. руб. на покриття дефіциту «Ради» (що у сумі за вісім років існування єдиної щоденної українськомовної газети Києва склало г4о-ı6о тис. руб.),

\footnotetext{
${ }_{34}$ Там само. - Спр.634. - Арк.65-69.

${ }_{35}$ Перед загальними зборами Наукового товариства ім. Шевченка. - Л., 1913. - С.7.

36 Журнал і публіка // Діло. - 1911. - №41. - С.3.

${ }^{37}$ Перед загальними зборами Наукового товариства ім. Шевченка. - С.12.

${ }^{38}$ Там само. - C.14.
} 
М.Грушевський зводив 6-поверховий фамільний будинок, який обійшовся йому у І6о тис. руб. Газети «Село» й «Засів», кошти на видання яких бралися з каси НТШ, припинили своє існування, оскільки іх регулярно штрафували. Однак загальна сума стягнень, накладених на «Засів», становила І,5 тис. руб. - такі гроші М.Грушевський міг запросто викласти зі своєї кишені, якби він був меценатом української справи.

Часопис «Село» зробив надзвичайно багато для пробудження національної свідомості передовсім селян. Тож передчасне закриття видання завдало величезної шкоди українській пресі, національному руху. Те, що «від дня виходу газети у світ 3 вересня 1909 р. вчений впродовж майже півтора року пильнував кожне ії число, перечитував рукописи, укладав зміст, вів інтенсивне листування зі співробітниками та авторами, впроваджуючи в життя розроблену редакційну політику» 39 , жодним чином не перекреслює той факт, що грошей на підтримку видання він зі своєї аж ніяк не порожньої кишені (в якій знаходилися чималі суми на домобудівництво або на збирання колекції килимів) так і не виділив. М.Грушевський умістив у «ЛНВ» некролог «Селу» під назвою «Недооцінювання», в якому звинуватив українську громадськість у тому, що вона, мовляв, не дбала про народну газету. Пишучи, що «громадянство повинно було щиро пожалувати сеї газетки, коли б воно відчувало потреби і завдання свого життя» ${ }^{40}$, автор обійшов питання власної відповідальності за ії долю. Є.Чикаленко теж міг би звести будинок на кілька поверхів, але він обрав «Раду», зазнавши з комерційного погляду лише збитків. Звісно, М.Грушевського можна й потрібно називати «конструктором модерної української нації», але наскільки прийнятна в такій конструкції філософія буржуа та комерсанта, котрий не бажає платити за продовження збиткових, утім суспільно корисних проектів? Питання риторичне.

Отже дослідження видавничої діяльності, епістолярної, публіцистичної спадщини М.Грушевського, його оточення, прихильників та ідеологічних супротивників дозволяє глибше розкрити не лише особливості українського національного життя на початку XX ст., але й причини (зрозуміло, не всі) поразки України у протистоянні із зовнішніми і внутрішніми ворогами. Наведені вище факти свідчать про безумовну важливість епістолярію та публіцистики як джерельної основи грушевськознавства, про їх роль у видавничій складовій суспільної праці М.Грушевського. Далеко не всі його листи опубліковано, не всі праці, які відображають масштаб, особливості видавничої діяльності, уведено в науковий обіг. Продовження й розширення студій, присвячених цій ділянці життя багатогранної та неоднозначної постаті вітчизняної історії минулого століття, має очевидне значення, особливо зважаючи, що видання часописів істотно збільшувало вагу та вплив тих, хто безпосередньо формував редакційну політику. Джерела також свідчать, що не варто ідеалізувати, тим більше міфологізувати на догоду кон'юнктурі діячів національного руху. М.Грушевський був людиною непересічною, талановитою, але аж ніяк не «безгрішним пророком». Його хиби та вади належать історії й також мають бути предметом фахових досліджень (зокрема в контексті видавничої діяльності в Києві г907-1914 рр.).

\section{REFERENCES}

1. Burlaka, H. (Comp.). (1997). Lystuvannia Mykhaila Hrushevskoho. Kyiv. [in Ukrainian].

2. Hekhter, M. (2005). Spohady: Lysty do M.Hrushevskoho. Kyiv. [in Ukrainian].

3. Horyn, V. (2002). Lysty M.Hrushevskoho do M.Kotsiubynskoho. Ukrainskyi istoryk, 1-4 (152-155), 436-464. [in Ukrainian].

\footnotetext{
${ }^{39}$ Панькова С. Публіцистика Михайла Грушевського як джерело... - С.99-100.

${ }^{40}$ Грушевський М.С. Твори: У 50 т. / Редкол.: П.Сохань, Я.Дашкевич, І.Гирич та ін. - Т.2: Серія «Суспільно-політичні твори (1907-1914)». - Л., 2005. - С.183.
} 
4. Hyrych, I. (1996). Arkbiv M.S.Hrushevskoho yak dzherelo dlia vyvchennia diialnosti vyznachnykh postatei ukrainskoho rukbu (Extended abstract of Candidate's thesis). Kyiv. [in Ukrainian].

5. Hyrych, I. (2016). Dosiahnennia i perspektyvy rozvytku suchasnoho hrushevskoznavstva (do 150-richchia vid dnia narodzhennia M.S.Hrushevskoho). Visnyk NAN Ukrainy, 11, 31-37. [in Ukrainian].

6. Hyrych, I. (2016). Mykhailo Hrushevskyi: konstruktor modernoi ukrainskoi natsii. Kyiv. [in Ukrainian].

7. Ivanytska, S. (2013). Lystuvannia Mykhaila Hrushevskoho: Lystuvannia Mykhaila Hrushevskoho ta Yuriia Tyshchenka. Ukrainskyi arkheohrafichnyi shchorichnyk: Nova seriia, 18, 748-761. [in Ukrainian].

8. Kovalskyi, M. \& Atamanenko, A. (2004). Teoretychne obgruntuvannia hrushevskoznavstva (do 70-littia Liubomyra Vynara). Problemy istorii Ukrainy: Fakty, sudzhennia, poshuky, 10, 30-41. [in Ukrainian].

9. Melnyk, O. (Comp.). (2012). Lystuvannia Mykhaila Hrushevskobo: Lystuvannia Mykhaila Hrushevskobo ta Yuriia Tyshchenka. Kyiv. [in Ukrainian].

10. Pankova, S. (2018). Publitsystyka Mykhaila Hrushevskobo yak dzherelo doslidzhennia suspilno-politychnoi dumky $v$ Ukraini kintsia $X I X$ - pochatku XX st. (Candidate's thesis). Kyiv. [in Ukrainian].

11. Pankova, S., Pryshliak, V. (Comps.). (2008). Lystuvannia Mykhaila Hrushevskoho: Lystuvannia Mykhaila Hrushevskoho ta Ivana Dzbydzhory. Kyiv; Niu-York; Paryzh; Lviv; Toronto. [in Ukrainian].

12. Pyrih, R. (1996). Hrushevskoznavstvo: stan ta perspektyvy rozvytku. Ukrainskyi istorychnyi zhurnal, 5, 71-82. [in Ukrainian].

13. Pyrih, R., Telvak, V. (2017). Mykhailo Hrushevskyi: biobrafichnyi narys. Kyiv. [in Ukrainian].

14. Starovoitenko, I., Todiichuk, O. (Comps.). (2010). Lystuvannia Mykhaila Hrushevskobo: Lystuvannia Mykhaila Hrushevskobo ta Yevbena Chykalenka. Kyiv; Niu-York; Paryzh; Lviv; Toronto. [in Ukrainian].

15. Vynar, L. (1995). Mykhailo Hrushevskyi: istoryk ta budivnychyi natsii: Statti ta materialy. Kyiv. [in Ukrainian].

16. Vynar, L. (1996). Vstup do nauky hrushevskoznavstva. Ukrainskyi istoryk, 4, 17-78. [in Ukrainian].

\author{
Ihor TKACHENKO \\ Candidate of Historical Sciences (Ph. D. in History), \\ Leading Research Fellow, \\ Sector of Social Sciences, \\ Scientific and Organizational Department of the Presidium of the NAS of Ukraine \\ (Kyiv, Ukraine), tkachenko@nas.gov.ua \\ ORCID: https://orcid.org/oooo-ooo2-8276-3778
}

\title{
M.Hrushevskyi's Publishing Activity in Kyiv in 1907-1914 As a Component of Hrushevskyi Studies: Epistolary and Journalistic Aspect
}

\begin{abstract}
The purpose of the study. The research is dedicated to the problems of considering the publishing activity of M.Hrushevskyi in the period before the World War I as the main direction of his social and political activity, and one of the aspects of Hrushevskyi's studies, the role and significance of which requires more attention from researchers of the life and social activities of M.Hrushevskyi. The research methodology is based on the principles of comprehensive analysis of sources representing the publishing activity of M.Hrushevskyi, his role as a publisher and the native head of "LNV", "Selo", "Zasiv". The use of the problem-search method combined with a critical analysis of studies devoted to M.Hrushevskyi gives an opportunity to discover the main aspects and features of the views of scientists on his publishing activities in the context of general social and political work. The scientific novelty of the study is in the determination of the place and significance of the publishing activity of M.Hrushevskyi as an important branch of the Hrushevskyi studies. Analysis of publications related to the life and work of M.Hrushevskyi before the outbreak of the World War I allows claiming that his publishing activity literally as well as an effective and constant control over "LNV", "Selo", "Zasiv" allowed M.Hrushevskyi to strengthen his position as a leader of the Ukrainian national movement. Conclusions. It was determined that publishing activity was one of the key areas of M.Hrushevskyi's common work. It is shown that the transfer of "LNV" to Kyiv in 1907 contributed not only to the unification of both parts of Ukraine, separated by borders, but also to the strengthening of his sole influence on the journal, which in a part can be considered as his private edition, with the help of which he became the №1 in the Ukrainian national movement. Therefore, the publishing activity of M.Hrushevskyi served not only to form the Ukrainian national consciousness and spread Ukrainian ideas, but also to increase his personal influence and significance in Ukrainian society.
\end{abstract}

Keywords: Hrushevskyi, publishing activity, Hrushevskyi studies, Ukrainian national movement. 